\title{
Mispronunciation of English Monophthong and Diphthong among Malay Native Speakers
}

\section{Nurul Izzah Kamarudin, Mafarhanatul Akmal Ahmad Kamal}

To Link this Article: http://dx.doi.org/10.6007/IJARBSS/v11-i10/11451～DOI:10.6007/IJARBSS/v11-i10/11451

Received: 18 August 2021, Revised: 14 September 2021, Accepted: 28 September 2021

Published Online: 13 October 2021

In-Text Citation: (Kamarudin \& Kamal, 2021)

To Cite this Article: Kamarudin, N. I., \& Kamal, M. A. A. (2021). Mispronunciation of English Monophthong and Diphthong among Malay Native Speakers. International Journal of Academic Research in Business and Social Sciences, 11(10), 814-822.

\section{Copyright: (c) 2021 The Author(s)}

Published by Human Resource Management Academic Research Society (www.hrmars.com)

This article is published under the Creative Commons Attribution (CC BY 4.0) license. Anyone may reproduce, distribute, translate and create derivative works of this article (for both commercial and non-commercial purposes), subject to full attribution to the original publication and authors. The full terms of this license may be seen at: http://creativecommons.org/licences/by/4.0/legalcode

$$
\text { Vol. 11, No. 10, 2021, Pg. } 814-822
$$

Full Terms \& Conditions of access and use can be found at http://hrmars.com/index.php/pages/detail/publication-ethics 


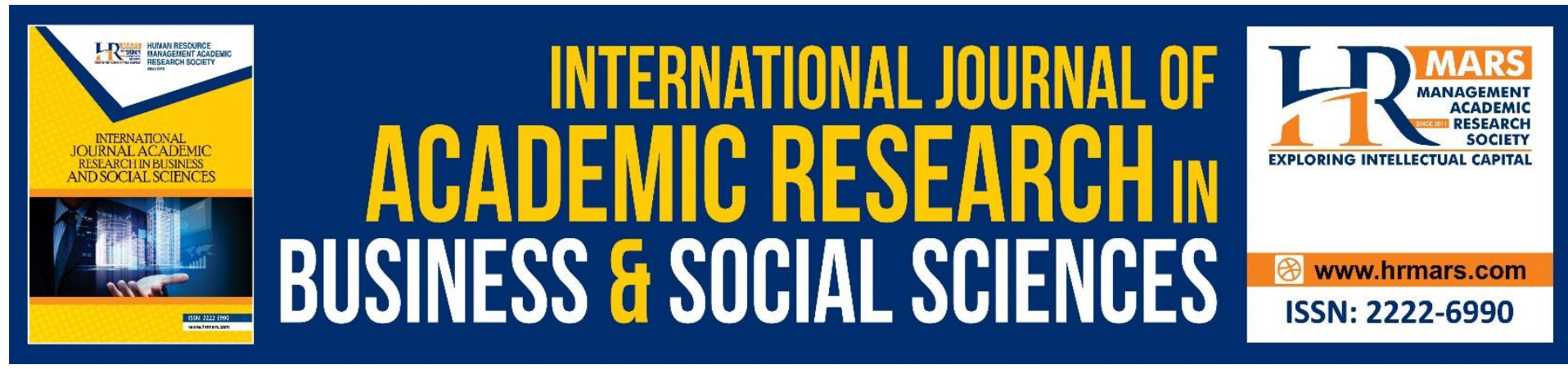

\title{
Mispronunciation of English Monophthong and Diphthong among Malay Native Speakers
}

\author{
Nurul Izzah Kamarudin ${ }^{1}$, Mafarhanatul Akmal Ahmad Kamal ${ }^{2}$ \\ ${ }^{1}$ The Academy of Language Studies, Universiti Teknologi MARA, 40450 Shah Alam, Selangor \\ Darul Ehsan, ${ }^{2}$ The Academy of Language Studies, Universiti Teknologi MARA, 40450 Shah \\ Alam, Selangor Darul Ehsan. \\ Email: izzah7724@gmail.com, mafarhanatulakmal@uitm.edu.my
}

\begin{abstract}
Due to phonological processes such as assimilation, certain vowels in Malaysian English (MalE) are pronounced differently than in Standard English. Vowel assimilation occurs frequently in MalE and results in pronunciation errors. Thus, the purpose of this study is to ascertain the most frequently mispronounced English vowel sounds by Malay native speakers as a result of the adaptation of sounds or phonemes from the Malay language (L1) to the English language (L2). The current study used a descriptive qualitative method to collect data by having 30 Malay native speakers participate in a pronunciation test. The error analysis approach is used to analyse the participants' pronunciation of 12 English words, which are then converted to phonetic transcription. The transcriptions of the participants' pronunciations are compared to the correct transcriptions in the Oxford Advanced Learner's Dictionary: International Student Edition (2010) to identify the participants' pronunciation errors. The findings revealed that Malay native speakers have difficulty pronouncing the monophthong /u:/ and diphthongs /əひ/ and /гә/. In conclusion, the mispronunciation of monophthongs and diphthongs among Malay native speakers is a result of the assimilation and substitution of sounds that are absent from Malay phonology in comparison to the English phonological system.
\end{abstract}

Keywords: Pronunciation, Error Analysis, Diphthong, Monophthong, Malay Native Speaker

\section{Introduction}

English has undergone copious changes throughout the British colonial period in Malaysia. Rashid et al. (2017) stated that English was reinforced in Malaysia's educational system in 2012 due to the plummeting of English among Malaysians. Despite the effort of implementing only Malay language in Malaysia to replace the overpower of the British, the widespread use of English in most countries has driven Malaysia to implement it as its second language. Since then, English has been an important second language (L2) in Malaysia after its first language (L1), which is Bahasa Malaysia. Due to the partial implementation of English among Malaysians, who come from a variety of ethnic groups such as Malay, Chinese, and Indian, Malaysians do not achieve high levels of proficiency in English due to their strong attachment to their mother tongue. However, they acknowledge the importance of English, thus inserted 
"a local flavor" into the way they speak English and produced a localised variety of the language namely Malaysian English (MalE) (Lee, 2015).

Malaysian English (MalE) is a unique way of conversing in English while maintaining the social identity as Malaysians (Kim \& Hall, 2019). This is due to globalisation, which is the primary cause of English variety in many countries (Rahim \& Manan, 2014). However, this issue has become more controversial among linguists as a result of the fact that the existence of English varieties results in a corrupted form of Standard English. Although Standard English is still being emphasised in Malaysia through education, the MalE variety is becoming more prominently used in society due to globalisation. MalE differs from Standard English in terms of the sound of certain vowels due to assimilation, thus leads to pronunciation errors. In order to acquire the pronunciation of L2, non-native speakers often simplify words through a certain phonological process because the sound production is unable to develop independently.

MalE has a tendency to reduce diphthongs as speakers do not stress on the glide between two vowels, thus producing monophthongs instead of diphthongs (Hashim, 2020) In one of the processes, namely assimilation, speakers tend to combine one sound with another sound in order for the sounds to be more alike or identical (Crystal, 1991 as cited in Lathifah, 2018). Assimilation normally takes place when there are two sounds that have similar features in place or manner of articulation (Dawood \& Atawneh, 2015). For example, the voiced sound /z/ in the word newspaper /nju:zperpə/ changes to voiceless sound /s/ when speakers pronounce it as /nju:speipə/. This happens because both sounds are fricative, and the only difference is the vibration in the vocal cord when articulating the sounds. The action of substituting certain sounds shows that assimilation produces the different pronunciation of words compared to the correct form, thus leads to pronunciation errors.

There has been previous research on assimilation and pronunciation errors in MalE. However, the majority of them were conducted on students and focused on Malaysians rather than Malay native speakers. Therefore, the current study aims to identify which monophthongs and diphthongs are commonly mispronounced by Malay native speakers, as well as to address the age and exposure gaps as factors influencing pronunciation.

\section{Literature Review}

The act of articulating words is referred to as pronunciation. Rather than relying solely on sounds to convey meaning, it employs phonetic symbols to represent the way a word is pronounced. Additionally, pronunciation refers to speakers' ability to use appropriate intonation and stress when they pronounce words, ensuring that listeners grasp the content correctly. Apart from the four essential skills for learning English, pronunciation is a critical feature or component that non-native English speakers must master while learning the language. Therefore, it is critical that speakers place equal emphasis on pronunciation as they do on other skills in order to become proficient users of English language.

Age plays an important role in acquiring pronunciation of a language. The brain substantially simplifies language understanding and output between the ages of 10 and 12. When lateralisation happens after puberty, however, neuroplasticity is eliminated and the maturational process of the brain is completed (Ritcher, 2019). The automatic aspect of 
language acquisition fades during this period of brain growth, presenting difficulties to learning a new language. In other words, if language learning does not begin at puberty, children's ability to learn languages as they get older is limited. Although some aspects of the language can be learned, complete mastery is exceedingly unlikely.

Thus, good pronunciation should be learned at a young age, as a speaker's mother tongue, or L1, has a significant influence on pronunciation Ambalegin and Suryani (2018) corroborate this by stating that the phonological difference between the mother tongue and the second language, $L 2$, which results in the transition of the mother tongue, has a negative effect on a speaker's pronunciation. As a result, phonological interference occurs during L2 pronunciation acquisition which includes the processes such as substitution, in which speakers exchange one class of sounds for another. Other than that, speakers may also substitute the syllable structure, in which syllables are reduced, omitted, or repeated, as well as assimilation, in which one sound is combined with another sound. As a result of these processes, incorrect pronunciation and grammatical properties of words that deviate from the conventional L2 are produced.

\section{Standard English Phonology}

The international phonetic alphabet (IPA) contains the Standard English spelling system, which non-native speakers can refer to when learning to acquire this language. The IPA is divided into two main sections: consonant and vowel. The vowel is further classified into two types: monophthong and diphthong.

Monophthongs are vowels that are articulated at the beginning and end of words. The term is derived from the Greek word 'mono', which means single, and '-pthong', which refers to sound or tone. It is categorised into two parts, which are short vowels and long vowels (Aziz et al., 2021). Short vowels consist of seven sounds which are /æ/ as in the word 'cat', /e/ as in the word 'pet', /I/ as in the word ' $f i t$ ', /D/ as in the word 'hot', / $\Lambda$ as in the word 'hut', / / / as in the word 'bull', and /ə/ as in the word 'the'. Meanwhile, long vowels comprise five sounds, which are /a:/ as in the word 'far', /3:/ as in the word 'burn', /כ:/ as in the word 'paw', /i:/ as in the word 'sheet', and /u:/ as in the word 'mood'.

Diphthongs are formed when two vowel sounds combine in a single syllable (Nordquist, 2019). There is a total of eight diphthongs in English (Dosia \& Rido, 2017). The first diphthong is /aI/ which sounds similarly to "eye". Secondly, the diphthong /ei/ creates sounds like "great". The third diphthong is /əv/, which sounds like "boat". Moreover, the fourth diphthong is /av/ and it creates sounds similar to "how". Fifth, the diphthong /eə/ sounds like "air". Meanwhile the sixth diphthong is /Iə/ which exists in the word "ear". Seventh, the diphthong /כI/ sounds like "boy". Lastly, the eight diphthong is /ひə/ which sounds similar to "sure".

\section{Difference in Phonology of English and Malay Languages}

English and Malay languages share identical vowels such as /a/, /e/, /i/, /o/, /u/ and /ə/ (Azmi, et al., 2016). For example, the /a/ sound occurs in both 'up' and 'anak' (child), both 'net' and 'kek' (cake) contain the /e/ sound, and both 'ill' and 'insang' (gill) contain the /i/ sound. In addition, both 'often' and 'oleh' (by) contain the /o/ sound, while 'unique' and 'yuran' (fee) contain the / $\mathrm{u} /$ sound. Similarly, the schwa /ə/ sound, can be heard in the words 'again' and 
'empuk' (tender). Besides, /æ/ appears in the word 'fake', / $\mathrm{p} /$ appears in the word 'hot', and /i:/ appears in the word 'fee'. However, when these alphabets and phonemes are analysed using contrastive analysis, the pronunciations of these alphabets and phonemes vary. For example, the letter 'a' is pronounced $/ \Lambda$ in Malay, but $/ \Lambda /, / a: /, / e /, / \partial /$, / eI/ and /æ/ in English (Priscilla et al., 2016). Additionally, Malay phonology contains only three diphthongs, whereas English phonology contains eight. The diphthongs in English are /aI/ in 'bite, /av/ in

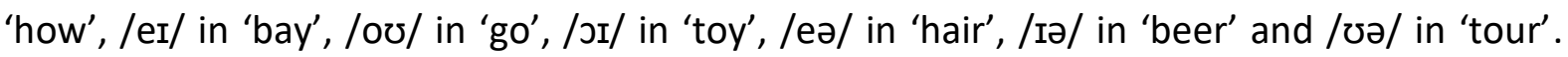
Meanwhile, the three diphthongs in Malay phonology are /ai/ in 'lain' (other), /au/ in 'laut' (sea) and /oi/ in 'boikot' (boycott).

\section{Mispronunciation of English Vowel}

Monophthongs are basic English vowels that have been taught from primary school. As a result, pronouncing them correctly should not be difficult for non-native speakers. Nevertheless, it was found that Malaysian pupils were more likely to mispronounce short vowels, with the error percentage for the sound /ə/ and /I/ are the third highest which is $15.4 \%$ (Nur Syahida \& Zairil, 2017). When it comes to long vowels, most speakers, particularly Malaysians, mispronounce them as short vowels due to the absence of their identical sounds in MalE, resulting in pronunciation errors.

Kho (2011) discovered that Malaysians have difficulty distinguishing between I/ and /i:/ or / $/$ and /u:/. In a research by Setyaningsih et al., (2019), non-native speakers were unable to distinguish between long vowel/i:/ and short vowel/I/, pronouncing the word cheese as / $\mathrm{fIz} /$ rather than /tfi:z/. Pronunciation errors involving diphthongs are also common in MalE. According to Phng (2017), the influence of Malay, Chinese, and Indian languages in MalE leads to diphthong pronunciation errors, with speakers failing to diphthongise the word "face." Furthermore, Setyaningsih et al., (2019) discovered that when pronouncing 'home,' 'house,' and 'counter,' speakers tend to replace /əo/ and /av/ with /o/.

\section{Methodology}

This study employed a descriptive qualitative method and included 30 Malay native speakers from the age of 18 to 54 years old, who have access to the WhatsApp application. Participants are chosen from Johor, which is considered to have no regional dialects, to minimise discrepancies due to the different regional dialects of Malay language such as Kelantanese Malay, Terengganuan Malay, Kedahan Malay, and Negeri Sembilan Malay. Furthermore, all participants must be able to clearly enunciate words without any speech problems such as dysarthria or apraxia. Table 1 shows the distribution of ages among participants who took part in the pronunciation test.

Table 1: Participants' Age Distribution

\begin{tabular}{cll}
\hline Factor & Frequency & Percent \\
\hline $\mathrm{n}$ & 30 & 99.99 \\
18 to 32 years old & 10 & 33.33 \\
33 to 43 years old & 10 & 33.33 \\
44 to 54 years old & 10 & 33.33
\end{tabular}

A pronunciation test consisting of 12 words containing the prepared categories of monophthongs and diphthongs were handed to the 30 participants. These words were 
adapted from the list of mispronounced words by participants in previous studies to ensure its reliability and validity (Kho, 2011; Priscilla Shak, 2016; Puspita, 2017; Nur Syahida \& Zairil, 2017; Setyaningsih et al., 2019). The participants were instructed to record their pronunciation of each word three times using WhatsApp voice recording in order to ensure accurate pronunciation. The recordings were listened five times in order to be phonetically transcribed and the pronunciation errors were carefully observed. To further validating the results of the pronunciation test, the phonetic transcription for the voice recordings were validated by three linguistics graduates. Next, the transcribed words pronounced by the speakers were compared with the correct transcription in the Oxford Advanced Learner's Dictionary: International Student Edition (2010). The deviations of pronunciation made by Malay native speakers were calculated by using the formula of percentage for the types of errors proposed by Sudijono (2008).

$P=\frac{F}{N} \times 100 \%$

In which,

P: Percentage of each error

F: Frequency of error occurred

$\mathrm{N}$ : Total number of the errors

\section{Findings and Discussion}

For monophthong, two words were tested for the sounds /æ/, while one word was tested for each of the sounds/u:/ and /i:/. In addition, for diphthongs, one word was used for the sound /ıә/, two words for the sounds/aI/ and /av/ and three words for the sounds/er/ and /əə/. The percentage of errors for monophthong and diphthong was attained based on the result in the pronunciation test by using the formula percentage for the types of errors introduced by Sudijono (2008). The total frequency of error for the sound /əv/ was 84 , thus it was divided by the number of words tested which was three. Therefore, the number of errors for the sound /əv/ was 28 . Table 1 illustrates the number of errors by dividing the overall frequency of error by the number of words examined to get the mean.

Table 2: The Percentage of Malay Native Speakers' Errors

\begin{tabular}{llll}
\hline Category & Sounds & Frequency & Percent \\
\hline $\mathrm{n}$ & & 97 & 100 \\
Monophthong & /u:/ & 22 & 23 \\
& /i:/ & 9 & 9 \\
& /æ/ & 0 & 0 \\
Diphthong & /Iə/ & 29 & 30 \\
& /əठ/ & 28 & 29 \\
& /aI/ & 9 & 9 \\
& /eI/ & 0 & 0 \\
& /av/ & 0 & 0
\end{tabular}

It was found that Malay native speakers revealed difficulties in pronouncing monophthong particularly the sound / $\mathrm{u}: /$ with a $23 \%$ error percentage among the other three monophthongs in the words of pronunciation test. The English sound /u:/ is a monophthong 
and categorised as a long vowel. Malay native speakers shortened the long vowel / $u$ :/ to produce the sound $/ \mho /$ because long vowels are not found in Malay phonology. Therefore, it is best for them to substitute them with short vowels when they pronounced the word 'move' as /mov/ instead of /mu:v/. Meanwhile, as for diphthongs, there are three sounds that are frequently mispronounced by Malay native speakers. The sound /əひ/ have the percentage of error of $28 \%$ while the sound /ıə/ has the percentage of $29 \%$. Table 3 shows the deviations of these three sounds produced by Malay native speakers.

Table 3: The Deviation of Diphthongs

\begin{tabular}{|c|c|c|c|c|}
\hline Sounds & Words & Dictionary Transcription & Speakers' Pronunciation & Deviation \\
\hline \multirow[t]{3}{*}{ /əઇ/ } & Home & hərm & hom & 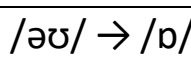 \\
\hline & Closely & kləusli & klosli & \\
\hline & Sold & səold & spld & \\
\hline /Іә/ & Theory & Өıәri & tiori & $/ \mathrm{I \partial} / \rightarrow$ /ID/ \\
\hline
\end{tabular}

The English diphthong /гə/ which comprises the vowels/I/ and /ə/is another sound that was mispronounced by 29 out of 30 speakers. /Iə/ is articulated by positioning the tongue in the front vowel /I/, then gliding to the centre to form the central vowel /ə/. This diphthong is substituted with /ID/ due to the influence of the Malay language on the spelling of the word because Malay native speakers pronounce the word 'theory' as 'teori' in Malay language, making it the most mispronounced diphthong by Malay native speakers. Other than that, the English diphthong /əv/ consists of two vowel sounds, which are /ə/ and / /. The articulation of this diphthong starts in the centre of the mouth where the tongue is in the position of vowel /ə/ before moving the tongue back rounded to a closer position of the vowel / $\mho /$. However, Malay native speakers tend to substitute the sound /əv/ with / $/$ / due to the absence of this diphthong in Malay phonology. This sound was mispronounced by 28 out of 30 speakers for this study.

Based on the data presented earlier, this study discovered that Malay native speakers face difficulties in differentiating short and long vowel sounds such as the monophthong / $\mathrm{u}$ :/ and /i:/ as well as diphthong /əo/ and /ıə/. Although the long vowel sound /i:/ was less mispronounced compared to the sound / $\mathrm{u}: /$, nine of the speakers still shortened it into short vowel. Similarly, the study conducted by Nur Syahida \& Zairil (2017) also has the same findings whereas the participants pronounced the long vowel sounds/i:/ and / :/ wrongly by shortening them. This shortening of long vowels may be resulted due to the fact that Malay phonology comprises only six vowels which are /a/, /e/, /i/, /o/, /u/, and /ə/. These vowel sounds are short except for some dialects among Malays where long vowels are used in order to put stress on the word and deliver paralinguistic meaning.

In addition, a total of 28 Malay native speakers substituted the sound /əv/ with / $\mathrm{b} /$ when they pronounced the words 'home', 'closely', and 'sold'. This pronunciation error occurs as diphthongs tend to be reduced in Malaysian English in which the glide between two different vowels weakens, thus produce monophthong instead (Hashim, 2020). Besides, 29 speakers also substituted /Iə/ with /ID/ when pronouncing the word 'theory'. Just like the findings from Kho (2011), Malay students in the study also pronounced the sound / Iə/ incorrectly due to the fact that their English pronunciation is affected by the influence of the Malay word which 
is 'teori'. Other than these two sounds, /aI/ was also mispronounced by 9 speakers when it comes to the word 'obliged' as they tend to pronounce it based on how the word is spelled. Based on the analysed data, the vowel sounds/æ/, /eI/, and/av/ were pronounced correctly by Malay native speakers because of their presence in Malay phonology. The words used to test the sound /æ/ 'rabbits' and 'having'. Additionally, none of the speakers mispronounced the sound /av/ in 'counter', and 'house'.

\section{Conclusion}

The purpose of this study was to identify the English monophthongs and diphthongs that Malay native speakers frequently mispronounce. All in all, this study discovered that Malay native speakers have difficulties pronouncing long vowel/u:/ as well as diphthongs /əv/ and /гә/. The absence of sounds in Malay phonology is the most likely cause of the speakers' pronunciation errors. It leads to the utilisation of replacement and assimilation phonological processes. This has a lot to do with mother tongue, which is one of the aspects that affects pronunciation. Furthermore, errors may be made as a result of age and exposure factors. Based on the data collected and analysed, the elder speakers tend to make more errors when pronouncing the words. Despite the assumption that greater age should lead to better language acquisition due to more exposure towards English, the process of language acquisition becomes more difficult as speakers age. Furthermore, they are most likely exposed to MalE rather than standard English for a longer period of time. As a result, the longer they use MalE, the more they acquire habituated to the incorrect form of English and experience greater difficulty pronouncing words correctly. This study discovered the common pronunciation errors among Malay native speakers. However, it focuses on the specific sounds of monophthong, and diphthong. In order to provide a more comprehensive analysis of Malay native speakers pronunciation errors in MalE, future research should include more sounds from these two categories, as well as sounds from other categories.

\section{Reference}

Ambalegin, \& Suryani, M. S. (2018). Mother Tongue Affecting the English Vowel Pronounciation of Batak Toba Adults. KnE Social Sciences, Vol 3 (4), 78-86.

Aziz, M., Rahayu, T., Permatasari , I., Maftuh, M. F., \& Ridho, M. (2021, February 4-5). An Error Analysis of English Monophthongs Pronunciation in Speaking. Proceedings of the First International Conference on Economics, Business and Social Humanities, ICONEBS 2020. doi:10.4108/eai.4-11-2020.2304542

Azmi, M. N., Ching, L. T., Jamaludin, N. B., Ramli, M. N., Razali, M. H., Amram, M. A., \& Jayakumar, K. A. (2016). The comparison and contrasts between English and Malay languages. Journal of English Education Vol 4 (2), 209-218.

Dawood, H. S., \& Atawneh, D. A. (2015). Assimilation of Consonants in English and Assimilation of the Definite Article in Arabic. American Research Journal of English and Literature Vol 1 (4), 9-15.

Dosia, P. A., \& Rido, A. (2017). Production of English Diphthongs: A Speech Study. Teknostatik Vol 15 (1), 21-35.

Hashim, A. (2020). Malaysian English. In K. Bolton, W. Botha, \& A. Kirkpatrick, The Handbook of Asian Englishes, First Edition (pp. 373-397). John Wiley \& Sons, Inc.

Kho, I. C. (2011). An Analysis of Pronounciation Errors in English of Six UTAR Chinese Studies Undergraduates. Universiti Tunku Abdul Rahman. 
Kim, L. S., \& Hall, S. J. (2019). Manglish : Malaysian English at its Wackiest. Marshall Cavendish International Asia Pte Ltd.

Lathifah, N. N. (2018). English Phonological Assimilation Applied in "English With Lucy" Channel on YouTube. Faculty of Humanities, Universitas Islam Negeri Maulana Malik Ibrahim Malang.

Lee, Z. E. (2015). Colloquial Malaysian English (CMalE): A problem or a cool phenomenon? Repositori Universitat Jaume I.

Nordquist, D. R. (2019). Basic Grammar: What Is a Diphthong? ThoughtCo. https://www.thoughtco.com/diphthong-phonetics-term-1690456

Nur Syahida, M. Y., \& Zairil, A. Z. (2017). Pronunciation Problems Among KUIS Students. International Islamic University College Selangor.

Phng, S. W. (2017). Vowel variations among speakers of Malaysian English. Graduate Theses and Dissertations.

Shak, P. C. S. (2016). Pronunciation Problems: A Case Study on English Pronunciation Errors of Low Proficient Students. International Journal of Language Education and Applied Linguistics (IJLEAL) , Vol 4, 25-35.

Puspita, S. E. (2017). Interference of Sambas Malay in Pronouncing English Consonant Sounds. Tanjungpura University.

Rahim, H. A., \& Manan, S. A. (2014). English in Malaysia: postcolonial and beyond. Frankfurt: Peter Lang.

Rashid, R. A., Basree, S., \& Yunus, K. (2017). Reforms in the policy of English language teaching in Malaysia. Policy Futures in Education Vol 15(1), 100-112.

Ritcher, K. (2019). English-Medium Instruction and Pronunciation: Exposure and Skills Development. Poland: Multilingual Matters.

Setyaningsih, K. P., Wijayonto, A., \& Suparno. (2019). English Vowels and Diphthongs Problems of Sundanese Learners. ELS Journal on Interdisciplinary Studies on Humanities Vol 2 (4), 571-581.

Sudijono, A. (2008). Pengantar Statistik Pendidikan. Jakarta: RajaGrafindo Persada. 